\title{
Skill-biased technological change in an endogenous growth model
}

Citation for published version (APA):

Hollanders, H. J. G. M., \& ter Weel, B. J. (1998). Skill-biased technological change in an endogenous growth model. MERIT, Maastricht Economic Research Institute on Innovation and Technology. MERIT Research Memoranda No. 016 https://doi.org/10.26481/umamer.1998016

Document status and date:

Published: 01/01/1998

DOI:

10.26481/umamer.1998016

Document Version:

Publisher's PDF, also known as Version of record

\section{Please check the document version of this publication:}

- A submitted manuscript is the version of the article upon submission and before peer-review. There can be important differences between the submitted version and the official published version of record.

People interested in the research are advised to contact the author for the final version of the publication, or visit the DOI to the publisher's website.

- The final author version and the galley proof are versions of the publication after peer review.

- The final published version features the final layout of the paper including the volume, issue and page numbers.

Link to publication

\footnotetext{
General rights rights.

- You may freely distribute the URL identifying the publication in the public portal. please follow below link for the End User Agreement:

www.umlib.nl/taverne-license

Take down policy

If you believe that this document breaches copyright please contact us at:

repository@maastrichtuniversity.nl

providing details and we will investigate your claim.
}

Copyright and moral rights for the publications made accessible in the public portal are retained by the authors and/or other copyright owners and it is a condition of accessing publications that users recognise and abide by the legal requirements associated with these

- Users may download and print one copy of any publication from the public portal for the purpose of private study or research.

- You may not further distribute the material or use it for any profit-making activity or commercial gain

If the publication is distributed under the terms of Article $25 \mathrm{fa}$ of the Dutch Copyright Act, indicated by the "Taverne" license above, 


\title{
Skill-Biased Technological Change in an Endogenous Growth Model
}

\author{
Hugo Hollanders \\ and
}

Bas ter Weel

MERIT, Maastricht University, P.O. Box 616, 6200 MD Maastricht, Tel: 043-3883873, Fax: 043-3216518, E-mail: h.hollanders@merit.unimaas.nl and b.terweel@merit.unimaas.nl

Useful comments were received from Robin Cowan, Huub Meijers, Pierre Mohnen, Luc Soete, Thomas Ziesemer and Adriaan van Zon. 


\section{$1 \quad$ Introduction}

When new technologies are introduced in the production process or when technological change is incorporated in an economic model, it is agreed upon that this reduces the demand for lowskilled labour relative to the demand for high-skilled labour. In general the rationale for this argument is that high-skilled workers and capital are complements, whereas high-skilled labour and low-skilled labour are substitutes, e.g. many routine assembly activities are replaced. ${ }^{1}$ In addition, it is acknowledged that high-skilled workers adapt more easily to changing technologies than their low-skilled colleagues. Finally, the computer revolution increases the productivity of high-skilled workers more than the productivity of low-skilled workers, leading to wage dispersion. ${ }^{2}$

One obvious reason for this dispersion is rapid and widespread diffusion of new technologies that go along with the evolution of the Information Society. ${ }^{3}$ Technological change, which has a broad systemic dimension in the information age and involves the reorganisation of many tasks and activities, appears to display a strong skill bias - see e.g. Autor, Katz and Krueger (1997), Berman, Bound and Griliches (1994) and Krueger (1993). ${ }^{4}$

Indeed, firms are increasingly prepared to pay for higher skilled workers as the costs associated

1 In Griliches (1969) this complementarity was due to the relative decline of the price of capital, while Denny and Fuss (1983) attribute this to the specific effects of technological changes. Murphy, Riddell and Romer (1998) discuss the debate on this issue in contemporary economics thoroughly. Their conclusion is that new technologies are relative complements with more educated labour which is closely related to the thesis that machinery and new technologies harm low-skilled workers.

2 The notion that economic growth eventually reduces dispersion and polarisation, the so-called Kuznets hypothesis is a related topic. The hypothesis that in the early stages of development wage dispersion is observed since only a few individuals have the required skills. Later on, the wage distribution narrows down because more individuals obtain the required skills.

3 See High Level Expert Group (1997). They argue that there is an urgent need to address investment towards human resources, knowledge and skill acquisition to prevent social dispersion and polarisation from happening.

$4 \quad$ Other studies on skill-biased technological change are e.g. Bound and Johnson (1992), Berman, Bound and Machin (1995), Card, Kramarz and Lemieux (1995), Howell and Wolff (1992), Machin (1996), Nickell (1996) and Nickell and Bell (1996). 
with the tangible part of new investments have decreased with time. Moreover, employers have replaced increasingly expensive, low-skilled (blue-collar) workers by relatively inexpensive highskilled (white-collar) workers - see e.g. Draper and Manders (1997). This indicates that the returns to investment in high-level education have increased and has been accompanied by a major upskilling of the labour force, thereby polarising the wage distribution in most of the countries. Typically, the service sector has retained or increased the share of high-skilled worker it employs, while both the manufacturing and service sectors are decreasing the number of bluecollar workers they employ. This shedding of unskilled labour at the sectoral level has occurred in most OECD countries in the last decade, as illustrated in Table 1.

Table 1

Employment Growth Breakdown by Skill Level in Manufacturing and Services

(annual growth rates in \%)

\begin{tabular}{|c|c|c|c|c|c|c|c|c|c|}
\hline \multirow{2}{*}{\multicolumn{2}{|c|}{ Country }} & \multicolumn{2}{|c|}{$\begin{array}{l}\text { Blue-Collar } \\
\text { Low-Skilled }\end{array}$} & \multicolumn{2}{|c|}{$\begin{array}{l}\text { Blue-Collar } \\
\text { High-Skilled }\end{array}$} & \multicolumn{2}{|c|}{$\begin{array}{l}\text { White-Collar } \\
\text { Low-Skilled }\end{array}$} & \multicolumn{2}{|c|}{$\begin{array}{l}\text { White-Collar } \\
\text { High-Skilled }\end{array}$} \\
\hline & & Man. & Ser. & Man. & Ser. & Man. & Ser. & Man. & Ser. \\
\hline US & (1983-1993) & -0.2 & 0.2 & -0.1 & 0.2 & -0.1 & 1.4 & 0.2 & 0.9 \\
\hline Canada & (1981-1991) & -0.7 & 0.1 & -0.2 & .. & 0.1 & 0.8 & 0.4 & 1.0 \\
\hline Japan & (1980-1990) & 0.1 & 0.3 & -0.2 & -0.1 & 0.5 & 1.3 & 0.4 & 0.9 \\
\hline Germany & $(1980-1990)$ & -0.8 & -0.2 & 0.2 & 0.3 & 0.2 & 1.0 & 0.3 & 0.6 \\
\hline France & $(1982-1990)$ & -1.4 & 0.2 & -0.3 & .. & -0.2 & 0.5 & 0.4 & 1.2 \\
\hline Italy & (1981-1991) & -0.5 & 0.6 & -1.0 & 0.1 & -0.1 & 1.2 & 0.2 & 1.0 \\
\hline Australia & $(1986-1991)$ & -0.6 & 0.5 & -0.3 & 0.1 & .. & 1.2 & 0.4 & 1.8 \\
\hline New Zealand & (1976-1991) & -0.5 & -1.0 & -1.3 & 0.3 & -0.1 & 0.8 & -0.1 & 2.3 \\
\hline
\end{tabular}

Source: OECD (1996)

5 There are, however, differences in occupational composition across countries. The manufacturing sectors of Japan and Italy tend to employ more high-skilled, blue-collar workers as opposed to the US and France. On the other hand, the US and France tend to employ a greater share of high-skilled, white-collar workers in their manufacturing sectors. In the service sector, the distribution of workers according to skill is skewed towards high-skill and low-skill white-collar workers with a greater share of high-skilled, white-collar workers in the French service sector. 
The contents of technology used in several papers differ widely. Arrow (1962), King and Robson (1993), Stokey (1988), Yang and Borland (1991) and Young (1991), (1993a) and (1993b) all use learning by doing. Grossman and Helpman (1989) and (1991a) and Judd (1985) use new varieties of consumer goods, whereas Aghion and Howitt (1992), Grossman and Helpman (1990) and (1991b) and Romer (1987) and (1990) use new varieties of factors. Intergenerational technology transfers are used as a content of technology by Prescott and Boyd (1987) whereas Becker, Murphy and Tamura (1990) and Rebelo (1991) use household's knowledge; firm's knowledge is used in Ziesemer (1991). Finally, Lucas (1988) and Romer (1986) use private knowledge spillovers in their endogenous growth models. ${ }^{6}$ From these studies, starting from the ancestor in the founding works of endogenous growth theory (Arrow 1962), economists have formalized and endogenized neoclassical growth theory based on to factors: capital and homogenous labour. Even models that introduce human capital explicitly in the production function, treat high-skilled and low-skilled workers as perfect substitutes (Lucas 1988) or introduce technology as a complement with both types of labour (Romer 1990). In both approaches there is no role for technological change to differently affect wages for workers with different levels of education and skills. ${ }^{7}$ In particular, there is no recognition that technological change can lead to wage dispersion.

This paper develops a model of endogenous growth with heterogenous labour, which leads to skill-biased technological change and wage dispersion. In order to do so, we discuss the changing skills profile in terms of a dynamic model.

\footnotetext{
For elaborate literature surveys see e.g. Aghion and Howitt (1998), Barro and Sala-i-Martin (1995), Harberger (1998), Lucas (1993), Romer (1994) Schneider and Ziesemer (1994) and Verspagen (1992).

$7 \quad$ An exception is Eicher (1996) who examines how interaction between endogenous human capital accumulation and technological change affect relative wages and economic growth. His model provides a theoretical foundation for the empirically observed relation between technological change and relative demand, supply and wages of skilled labour.
} 


\section{The Changing Skills Profile}

\section{Consumers}

We consider a closed economy with competitive markets populated by a large number of heterogenous Ramsey consumers. They have standard, discounted, constant elasticity preferences:

$$
U_{t, s}=\frac{C_{t, s}^{1-\sigma}-1}{1-\sigma} e^{-\rho t}
$$

where the discount rate $\rho$ and the coefficient of relative risk aversion $\sigma$ are both positive. $C_{t, s}$ is defined as consumption of person $I$ with skill level $s$ at time $t . s$ is uniformly distributed over a range $\left[s_{0}, s_{l}\right]$. For each skill level $s$, there is only one individual $I$. These skills can be viewed as the ability this individual is born with.

Capital accumulation - for individual $I$ with skill level $s$ - is, as usual, defined as net income minus consumption:

$$
\dot{K}_{t, s}=(1-\tau) r_{t} K_{t, s}+(1-\tau) w_{t}\left(1-u_{s}\right) H_{t, s}-C_{t, s}
$$

where $\tau$ is a capital income tax for both physical and human capital, $r_{t}$ is the return on physical capital $K_{t, s}$ at time $t, w_{t}$ the return on human capital $H_{t, s}$, and $\left(1-u_{s}\right)$ is the amount of time spent by person $I$ with skill level $s$ to produce output. This budget constraint implies that all wealth that is generated - or all savings - is immediately transformed into physical capital.

The accumulation of human capital is skill-biased because individuals with a higher skill level profit more from technological progress $\left(A_{t}\right)$ than individuals with a lower level of human capital. Assuming skill levels between zero and one we observe from equation (3) that individuals with a higher skill level profit exponentially from an increase in technological progress 


$$
\dot{H}_{t, s}=A_{t}^{s} u_{s} H_{t, s}^{\beta} B_{t}^{\gamma}-\mu H_{t, s}
$$

with $0<\beta<1$ and $0 \leq s \leq 1$. $u_{s}$ is the time spent to accumulate human capital and $\mu$ is the depreciation rate of human capital. $B_{t}$ is public knowledge provided publicly whereas $A_{t}$ is provided privately and, as in Romer (1986) and Ziesemer (1991) it is assumed that no public action is taken to influence the supply of private knowledge. ${ }^{8}$ The stock of public knowledge is enhanced at some costs that are collected as capital income taxes $\tau$ - cf. equation (2).

Maximizing utility in equation (1) subject to the budget constraint (equation (2)) and human capital accumulation (equation (3)) leads to the following Hamiltonian

$$
\begin{aligned}
\Omega=\left(\frac{C_{t, s}^{1-\sigma}-1}{1-\sigma}\right) e^{-\rho t}+\lambda_{1}\left(A_{t}^{s} u_{s} H_{t, s}^{\beta} B_{t}^{\gamma}-\mu H_{t, s}\right) \\
\\
\quad+\lambda_{2}\left((1-\tau) r_{t} K_{t, s}+(1-\tau) w_{t}\left(1-u_{s}\right) H_{t, s}-C_{t, s}\right)
\end{aligned}
$$

Solving this Hamiltonian results in a standard Euler equation for individual $I$ with skill level $s:^{9}$

$$
\hat{C}_{t, s}=\left(\frac{(1-\tau) r-\rho}{\sigma}\right)
$$

where the after-tax return on capital $(1-\tau) r$ has to exceed the discount rate $\rho$. In the steady state the rental rate $r$ has to be constant because the growth of the marginal product of capital equals zero. $^{10}$

8 The distinction between private and public knowledge in this respect is comparable to that between applied and fundamental knowledge.

9 See Appendix A for mathematical proof.

10 Ziesemer (1995) alternatively considers an open economy and derives a constant rate of $r$ by incorporating imports, exports and foreign debt. 
Optimizing with respect to $H_{t, s}$ yields the growth rate of human capital $\hat{H}_{t, s}$ which depends both on the growth rates of private and public knowledge accumulation:

$$
\hat{H}_{t, s}=\frac{s \hat{A}_{t}+\gamma \hat{B}_{t}}{1-\beta}
$$

Equation (5) is of central importance to our analysis. The equation shows that public knowledge accumulation adds an unbiased amount of human capital accumulation to the individual's existing human capital stock. This equation also indicates that private human capital accumulation is biased and depends on the skill level an individual incorporates.

In order to compute the overall level of human capital we have to integrate equation (5) from zero to the maximum level of skills:

$$
H_{t}=\int_{0}^{1} H_{t, s} d s
$$

Since we have normalized the impact of skills this leads to ${ }^{11}$

$$
H_{t}=\int_{0}^{1} H_{t, s} d s=\frac{(1-\beta)\left(e^{\left(\frac{\hat{A_{t}+\gamma \hat{B}_{t}}}{1-\beta}\right) t}-e^{\left.\left(\frac{\gamma \hat{B}_{t}}{1-\beta}\right) t\right)}\right.}{t \hat{A}_{t}}
$$

Now, some straightforward calculations show that the steady state growth rate of the overall level of human capital converges to

$$
\lim _{t \rightarrow \infty} \hat{H}_{t}=-\frac{1}{t}+\frac{\gamma \hat{B}_{t}}{1-\beta}+\left(\frac{\hat{A}_{t}}{1-\beta}\right)\left(\frac{1}{1-e\left(\frac{-\hat{A}_{t}}{1-\beta}\right) t}\right)=\frac{\hat{A}_{t}+\gamma \hat{B}_{t}}{1-\beta}
$$

11 See Appendix B for mathematical proof. 
which is equal to the growth rate of human capital of the individual with the highest ability $s=1$. This result indicates that the skill bias increases because less and less individuals embody ever more human capital. Furthermore, equation (7) shows that the growth rate of human capital approaches this steady-state value asymptotically from below, as shown in Figure 1.

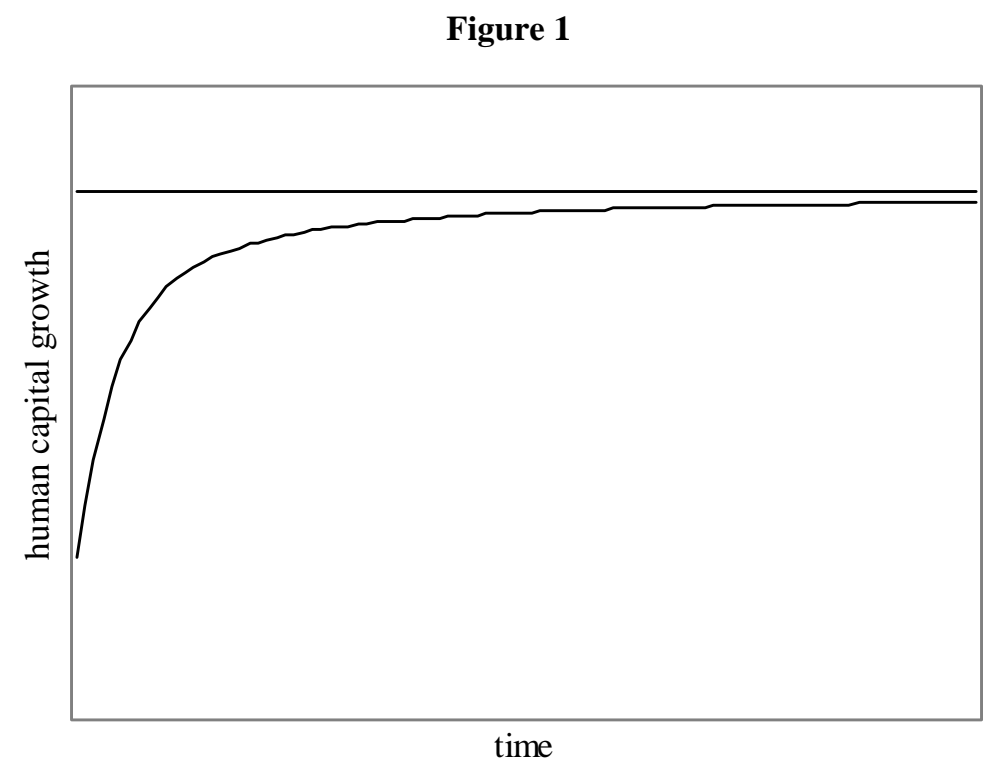

\section{Firms}

Firms allocate human capital between final goods production and technology production. Using $(1-\phi)$ of the human capital stock available to the firm, they produce output $Y_{t}$ using a standard increasing returns-to-scale Cobb-Douglas production function with labour saving technological change: ${ }^{12}$

12 Doubling the traditional inputs physical and human capital will double the level of output. However, doubling all three inputs, thus also the stock of private knowledge, will more than double the level of output. 


$$
Y_{t}=K_{t}^{\alpha}\left(A_{t} \int_{0}^{1}\left((1-\phi)\left(1-u_{s}\right)\right) H_{t, s} d s\right)^{v}
$$

where $0<\phi<1, \alpha>0, v>0$ and $\alpha+v=1$. Second, firms dedicate $\phi$ of their available human capital stock to enhance technological progress:

$$
\dot{A_{t}}=\left(\int_{0}^{1}\left(\phi\left(1-u_{s}\right)\right) H_{t, s} d s\right)^{\delta} A_{t}^{\xi}
$$

where $0<\delta<1,0<\xi<1$ and $\delta+\xi<1$. The second restriction $(0<\xi<1)$ is in line with recent empirical findings which show that the growth predictions of traditional models with $\delta=\xi=1$ (e.g. Uzawa (1965) and Romer (1986)) contradict post-war growth experiences for the major OECD countries (Jones, 1995b). This is confirmed by the steady-state solution for $\phi$ which shows that the traditional specification $\delta=\xi=1$ can be ruled out (see equation (C.11) in appendix C). Furthermore, we make the restriction that the production of technology exhibits decreasing returns-to-scale (e.g. Romer 1990). ${ }^{13}$

The firms maximize profits according to the following Hamiltonian:

$$
\begin{aligned}
\Pi=K_{t}^{\alpha}\left(A_{0} \int_{0}^{1}\left((1-\phi)\left(1-u_{s}\right)\right) H_{t, s} d s\right)^{v}-r K_{t}- \\
\\
\quad w_{t} \int_{0}^{1}\left(1-u_{s}\right) H_{t, s} d s+\lambda_{3}\left(\int_{0}^{1}\left(\phi\left(1-u_{s}\right)\right) H_{t, s} d s\right)^{\delta} A_{t}^{i}
\end{aligned}
$$
balanced growth path is consistent with an increasing number of persons devoted to technology production. 
Taking partial derivatives with respect to the control variables $K_{t}, H_{t, f}$ and $\phi$, and the state variable $A_{t}$, yields the following expressions for the growth rate of the capital stock, the human capital stock available to the firm (defined as $H_{t, f}$ ) and the stock of private knowledge ${ }^{14}$ :

$$
\begin{aligned}
& \hat{K}_{t}=\left(\frac{(1+\delta-\xi) \gamma}{(1-\xi)(1-\beta)-\delta}\right) \hat{B}_{t} \\
& \hat{H}_{t, f}=\left(\frac{(1-\xi) \gamma}{(1-\xi)(1-\beta)-\delta}\right) \hat{B}_{t} \\
& \hat{A}_{t}=\left(\frac{\delta \gamma}{(1-\xi)(1-\beta)-\delta}\right) \hat{B}_{t}
\end{aligned}
$$

The restriction $\delta+\xi<1$ ensures that the growth rate of the physical capital stock in equation (10) is positive. ${ }^{15}$ These equations also show that an increase in $\beta$ and $\gamma$, the effectiveness of human capital respectively public knowledge in the accumulation of human capital, has a positive effect on the growth rates in equations (10) - (12). An increase in $\xi$ and $\delta$, the effectiveness of private knowledge respectively human capital in the production of private knowledge, has similar positive effects.

\section{Government}

The government collects capital income taxes $(\tau)$ on both human and physical capital to finance the accumulation of public knowledge:

14 See Appendix C for mathematical proof.

15 In addition, equation (11) reconfirms our restriction that $\xi<1$. 


$$
\dot{B}_{t}=\tau r K_{t}+\tau w_{t}\left(\int_{0}^{1}\left(1-u_{s}\right) H_{t, s} d s\right)
$$

Public knowledge is invested in the accumulation of human capital as can be observed from equation (3). The intention of the government is to distribute income and therefore implicitly skills more equally. However, the collection of additional capital income taxes has both a positive and negative effect. Since the taxes are used to stimulate the level of fundamental knowledge it has a positive effect on overall productivity. On the other hand, additional capital income taxes have a negative effect on the accumulation of physical and human capital as can be seen from equation (2).

In Appendix D we show how to express the growth rate of the physical capital stock in terms of the parameters of the model. Combining equations (D.2) and (10), we can solve for the growth rate of public knowledge $B_{t}$

$$
\hat{B}_{t}=\frac{((1-\xi)(1-\beta)-\delta)((1-\tau) r-\rho)}{(1-\xi+\delta) \gamma \sigma}
$$

with $(1-\xi)(1-\beta)-\delta>0$. After careful consideration, we observe that capital income taxes have a negative effect on the growth rate of public knowledge. This conclusion, although at first site surprising, is rather straightforward. From common knowledge we can obtain that an increase in capital income taxes hurts the accumulation of both physical and human capital. Using equation (13) it is thus straightforward that once $\tau$ is increased, this hurts both physical and human capital accumulation. The first effect, an increase in $\tau$, increases the accumulation of public knowledge, whereas the second effect, deterioration of physical and human capital accumulation, has a negative effect on the accumulation of public knowledge. From equation (14) we then observe that the second effect dominates. 
Once we have solved the growth rate of public knowledge we can reexpress equation (10) - (12) in the parameters of our model. This results in equations (10') - (12')

$$
\begin{gathered}
\hat{K}_{t}=\frac{(1-\tau) r-\rho}{\sigma} \\
\hat{H}_{t}=\frac{(1-\xi)((1-\tau) r-\rho))}{(1-\xi+\delta) \sigma} \\
\hat{A}_{t}=\frac{((1-\tau) r-\rho)) \delta}{(1-\xi+\delta) \sigma}
\end{gathered}
$$

From these three equations we observe that capital income taxes have a negative effect on the growth rate of all three variables. The rationale is intuitively straightforward and consistent with the fact that negative externalities have negative effects on growth rates.

\section{Closing the model: skill-biased technological change}

Technological progress originating in the private sector leads to increases in the efficiency of human capital production biased towards individuals with higher abilities. This can be shown by assuming two individuals with abilities $s_{i}$ and $s_{j}$, where $s_{i}>s_{j}$. Using equation (5) we obtain:

$$
\frac{\hat{H}_{s_{i}}}{\hat{H}_{s_{j}}}=\frac{s_{i} \hat{A}_{t}+\gamma \hat{B}_{t}}{s_{j} \hat{A}_{t}+\gamma \hat{B}_{t}}
$$

Now an increase in the growth rate of private knowledge leads to a relative increase in the growth rate of the higher skilled individual, i.e. a skill-biased increase: 


$$
\frac{\partial\left(\hat{H}_{s_{i}} / \hat{H}_{s_{j}}\right)}{\partial \hat{A}_{t}}=\frac{\left(s_{i}-s_{j}\right) \gamma \hat{B}_{t}}{\left(s_{j} \hat{A_{t}}+\gamma \hat{B}_{t}\right)^{2}}>0
$$

With respect to government intervention, we obtain the opposite result. An increase in the growth rate of public knowledge leads to a relative increase in the growth rate of the lower skilled individual:

$$
\frac{\partial\left(\hat{H}_{s_{i}} / \hat{H}_{s_{j}}\right)}{\partial \hat{B}_{t}}=\frac{\left(s_{j}-s_{i}\right) \gamma \hat{B}_{t}}{\left(s_{j} \hat{A}_{t}+\gamma \hat{B}_{t}\right)^{2}}<0
$$

This result shows that there is scope for the government to reduce the effects of skill-biased technological change which are prevalent in the private sector. 


\section{$3 \quad$ Concluding Remarks}

In a globally competitive environment, one in which technology can quickly change the skills that are in demand, as shown above, systems for providing adequate skills to workers are needed. We have shown how public and private resources can be applied to invest in human resources, i.e. human capital. However, private investment (through an increase in $A$ ) leads to skill-biased technological progress in favour of the high-skilled. This notion of skill-biased technological change is in particular important with respect to the fast and rapid diffusion of knowledge and information that go along with the evolution of the Information Society. The upskilling within economies is confirmed by changes in employment by occupation. Professional and technical workers, the most highly skilled occupational category, have the highest or second highest employment growth rate in all countries. Second, relatively low-skill categories, such as agricultural workers and transport and production workers and labourers often have the lowest employment growth rates. ${ }^{16}$

The model also shows that there is scope for government intervention. The government can invest in its citizens by increasing the general level of knowledge. We have shown that lower skilled individuals profit more from this policy measure than higher skilled individuals. However, the government finances its expenditures by a capital income tax. The collection of additional capital income taxes has a positive effect on overall productivity but a negative effect on the accumulation of physical and human capital.

Moreover, we have shown that capital income taxes have a negative effect on the growth rate of public knowledge. The explanation is that an increase in the tax rate increases the accumulation of public knowledge but the effect of the deterioration of physical and human capital accumulation outweighs the marginal increase in the accumulation of public knowledge. Therefore, we can conclude that the government can reduce the skill bias by investing in the general level of human capital but that it cannot increase the tax rate for ever.

\footnotetext{
However, some occupational categories not considered particularly high-skilled, such as sales workers, clerical and related workers, and service workers have shown relatively strong employment growth.
} 
Further research with regard to government intervention is therefore required. In order to do so, we extend our model with a larger government component and try to see how it can reduce skillbiased technological change and deal with or stop the polarisation of the Western societies.

Further research with respect to our general model is also a future target. Several ways to extend our model are present. Particularly, the incorporation of unemployment and labour-market frictions and externalities are an important and new line of research. In addition, an extension in the direction of other new growth theory models is possible. Finally, an empirical application of our theoretical results might be a nice way to prove our point. 


\section{References}

Aghion, P. and P. Howitt (1992), A Model of Growth through Creative Destruction, Econometrica, Vol. 60, No. 2, pp. 323-51.

Aghion, P. and P. Howitt (1998), Endogenous Growth Theory, MIT Press, Cambridge MA.

Arrow, K.J. (1962), The Economic Implications of Learning by Doing, Review of Economic Studies, Vol. 29, pp. 155-73.

Autor, D.H., L.F. Katz and A.B. Krueger (1997), Computing Inequality: Have Computers Changed the Labor Market?, National Bureau of Economic Research Working Paper No. 5956.

Barro, R.J. and X. Sala-I-Martin (1995), Economic Growth, New York: McGraw-Hill.

Becker, G.S., K.M. Murphy and R. Tamura (1990), Human Capital, Fertility and Economic Growth, Journal of Political Economy, Vol. 98, No. 1, pp. 13-37.

Berman, E., J. Bound and Z. Griliches (1994), Changes in the Demand for Skilled Labor within US Manufacturing: Evidence from the Annual Survey of Manufactures, Quarterly Journal of Economics, Vol. CIX, No. 2, pp. 367-97.

Berman, E., J. Bound and S. Machin (1995), Implications of Skill-Biased Technological Change: International Evidence, Expert Report on Technology, Productivity and Employment: Macroeconomic and Sectoral Evidence, Paris, OECD.

Bound, J. and G. Johnson (1992), Changes in the Structure of Wages in the 1980's: An Evaluation of Alternative Explanations, American Economic Review, Vol. 82, No. 3, pp. 371-93.

Card, D., F. Kramarz and T. Lemieux (1995), Changes in the Relative Structure of Wages and Employment: A Comparison of the US, Canada and France, Princeton Working Paper.

Denny, M. and M. Fuss (1983), The Effects of Factor Prices and Technological Change on the Occupational Demand for Labour: Evidence from Canadian Telecommunications, The Journal of Human Resources, Vol. XVII, No. 2, pp.

Draper, and Manders (1997), Structural Changes in the Demand for Labour, De Economist, Vol. 145, No. 4, pp. 521-46.

Eicher, T.S. (1996), Interaction between Endogenous Human Capital and Technological Change, Review of Economic Studies, Vol. 63, pp. 127-44.

Griliches, Z. (1969), Capital-Skill Complementary, The Review of Economics and Statistics, Vol LI, pp. 465-68.

Grossman, G.M. and E. Helpman (1989), Product Development and International Trade, Journal of Political Economy, Vol. 97, No. 6, pp. 1261-83.

Grossman, G.M. and E. Helpman (1990), Comparative Advantage and Long Run Growth, 
American Economic Review, Vol. 80, pp. 796-815.

Grossman, G.M. and E. Helpman (1991a), Quality Ladders in the Theory of Growth, Review of Economic Studies, Vol. 58, pp. 43-61.

Grossman, G.M. and E. Helpman (1991b), Quality Ladders and Product Cycles, Quarterly Journal of Economics, Vol. 106, pp. 557-86.

Harberger, A.C. (1998), A Vision of the Growth Process, American Economic Review, Vol. 88, No. 1, pp. 1-32.

High Level Expert Group (1997), Building the European Information Society for Us All, European Commission.

Howell, D. and E. Wolff (1992), Technical Change and the Demand for Skills by US Industries, Cambridge Journal of Economics, Vol. 16, pp. 128-46.

Jones, C.I. (1995a), R\&D-Based Models of Economic Growth, Journal of Political Economy, Vol. 103, No. 4, pp. 759-784.

Jones, C.I. (1995b), Time Series Tests of Growth Models, Quarterly Journal of Economics, Vol. CX, pp. 495-525.

Judd, K.L. (1985), On the Performance of Patents, Econometrica, Vol. 53, No. 3, pp. 567-85.

King, M.A. and M.H. Robson (1993), A Dynamic Model of Investment and Endogenous Growth, Scandinavian Journal of Economics, Vol. 95, No. 4, pp. 445-66.

Krueger, A.B. (1993), How Computers Have Changed the Wage Structure: Evidence from Micro Data 1984-1989, Quarterly Journal of Economics, Vol. CVIII, pp. 33-60.

Lucas, R.E. Jr. (1988), On the Mechanics of Economic Development, Journal of Monetary Economics, Vol. 22, pp. 3-42.

Lucas, R.E. Jr. (1993), Making a Miracle, Econometrica, Vol. 61, pp. 251-72.

Machin, S. (1996), Changes in the Relative Demand for Skill in the UK, in Booth, A. and D. Snower (eds.), Acquiring Skills, Cambridge: CUP.

Murphy, K.M., W.C. Riddell, and P.M. Romer (1998), Wages, Skills and Technology in the United States and Canada, CIAR Working Paper ECWP-98.

Nickell, S.J. (1996), Unemployment and Wages in Europe and North America, mimeo, Institute of Economics and Statistics, University of Oxford.

Nickell, S.J. and B. Bell (1996), Changes in the Distribution of Wages and Unemployment in OECD Countries, American Economic Review, Papers and Proceedings, Vol. 86, No. 2, pp. 302-08.

OECD (1996), Technology, Productivity and Job Creation, Vol. 2, Analytical Report, OECD, Paris. 
Prescott, E.C. and J.H. Boyd (1987), Dynamic Coalitions: Engines of Growth, American Economic Review, Vol. 77, No. 2, pp. 63-7.

Rebelo, S. (1991), Long-Run Policy Analysis and Long-Run Growth, Journal of Political Economy, Vol. 99, No. 3, pp. 500-21.

Romer, P.M. (1986), Increasing Returns and Long-Run Growth, Journal of Political Economy, Vol. 94, No. 5, pp. 1002-37.

Romer, P.M. (1987), Growth Based on Increasing Returns Due to Specialization, American Economic Review, Vol. 77, No. 2, pp. 56-62.

Romer, P.M. (1990), Endogenous Technological Change, Journal of Political Economy, Vol. 98, No. 5, Part 2, pp. s71-s102.

Romer, P.M. (1994), The Origins of Endogenous Growth, Journal of Economic Perspectives, Vol. 8, No. 1, pp. 3-22.

Schneider, J. and T. Ziesemer (1995), What's New and What's Old in New Growth Theory? Endogenous Technology, Microfoundation and Growth Rate Predictions - A Critical Overview, Zeitschrift für Wirtschaft- und Sozialwissenschaften, Vol. 115, No. 3, pp. 144.

Stokey, N. (1988), Learning by Doing and the Introduction of New Goods, Journal of Political Economy, Vol. 96, No. 4, pp. 701-47.

Uzawa, H. (1965), Optimum Technical Change in an Aggregative Model of Economic Growth, International Economic Review, Vol. 6, No. 1, pp. 18-31.

Verspagen, B. (1992), Endogenous Innovation in Neoclassical Growth Model: A Survey, Journal of Macroeconomics, Vol. 14, No. 4, pp. 631-62.

Yang, X. and J. Borland (1991), A Microeconomic Mechanism for Economic Growth, Journal of Political Economy, Vol. 99, No. 3, pp. 460-82.

Young, A. (1991), Learning by Doing and the Dynamic Effects of International Trade, Quarterly Journal of Economics, Vol. 106, pp. 369-405.

Young, A. (1993a), Invention and Bounded Learning by Doing, Journal of Political Economy, Vol. 101, No. 3, pp. 443-72.

Young, A. (1993b), Substitution and Complementarity in Endogenous Innovation, Quarterly Journal of Economics, Vol. 108, pp. 775-807.

Ziesemer, T. (1991), Human Capital, Market Structure and Taxation in a Growth Model with Endogenous Technical Progress, Journal of Macroeconomics, Vol. 13, pp. 47-68.

Ziesemer, T. (1995), Growth with Imported Capital Goods, Limited Export Demand and Foreign Debt, Journal of Macroeconomics, Vol. 17, No. 1, pp. 31-53. 


\section{Appendix A}

Consumers maximize life-time utility with respect to the budget constraint and their human capital accumulation function. This results in the Hamiltonian $\Omega$, which is defined as

$$
\Omega=\left(\frac{C_{t, s}^{1-\sigma}-1}{1-\sigma}\right) e^{-\rho t}+\lambda_{1}\left(A_{t}{ }^{s} u_{s} H_{t, s}^{\beta} B_{t}^{\gamma}-\mu H_{t, s}\right)+\lambda_{2}\left((1-\tau) r_{t} K_{t, s}+(1-\tau) w_{t}\left(1-u_{s}\right) H_{t, s}-C_{t, s}\right.
$$

The control variables in the Hamiltonian are $C_{t, s}$ and $u_{s}$. Taking partial derivatives with respect to the control variables gives us equation (A.1) and (A.2):

$$
\begin{gathered}
\frac{\partial \Omega}{\partial C_{t, s}}=C_{t, s}^{-\sigma} e^{-\rho t}-\lambda_{2}=0 \\
\frac{\partial \Omega}{\partial u_{s}}=\lambda_{1} A_{t}^{s} H_{t, s}^{\beta} B_{t}^{\gamma}-\lambda_{2}(1-\tau) w_{t} H_{t, s}=0
\end{gathered}
$$

Taking partial derivatives with respect to the state variables $H_{t, s}$ and $K_{t, s}$ gives the following pair of differential equations:

$$
\begin{gathered}
\dot{\lambda}_{1}=-\frac{\partial \Omega}{\partial H_{t, s}}=-\lambda_{1}\left(\beta A_{t}^{s} u_{s} H_{t, s}^{\beta-1} B_{t}^{\gamma}-\mu\right)-\lambda_{2}(1-\tau) w_{t}\left(1-u_{s}\right) \\
\dot{\lambda}_{2}=-\frac{\partial \Omega}{\partial K_{t, s}}=-\lambda_{2}(1-\tau) r_{t}
\end{gathered}
$$

Dividing equation (A.4) by $\lambda_{2}$, taking growth rates of equation (A.1) and equating the results gives us the solution for individual $I$ with skill level $s$. This is a standard Euler equation:

$$
\hat{C}_{t, s}=\left(\frac{(1-\tau) r-\rho}{\sigma}\right)
$$


From now on we drop the subscript $t$ for the rental rate $r$, as this rental rate is constant in our steady state analysis.

Dividing equation (A.3) by $\lambda_{1}$, making use of equation (A.2) and then express this in growth rates gives us the solution for $\hat{H}_{t, s}$ :

$$
\hat{H}_{t, s}=\frac{s \hat{A}_{t}+\gamma \hat{B}_{t}}{1-\beta}
$$

Dividing equation (A.4) by $\lambda_{2}$ and expressing equation (A.2) in growth rates results in the costate variables which satisfy

$$
\begin{gathered}
\hat{\lambda}_{2}=-(1-\tau) r \\
\hat{\lambda}_{1}=\hat{\lambda}_{2}+\hat{w}_{t}=-(1-\tau) r+\hat{w}_{t}
\end{gathered}
$$

Dividing equation (A.3) by $\lambda_{1}$, making use of equation (A.2) and solving for $u_{s}$, gives us the following expression

$$
u_{s}=\frac{\hat{H}_{t, s}+\mu}{(1-\beta)\left(\hat{H}_{t, s}+\mu\right)-\hat{\lambda}_{1}+\mu}
$$

Making use of equation (A.6), (A.7) and (A.8), and assuming no depreciation of human capital $(\mu=0)$, this expression can be rewritten as

$$
u_{s}=\frac{s \hat{A}_{t}+\gamma \hat{B}_{t}}{(1-\beta)\left(s \hat{A}_{t}+\gamma \hat{B}_{t}+(1-\tau) r-\hat{w}_{t}\right)}
$$




\section{Appendix B}

From equation (A.6), we can in a straightforward way calculate the solution for the level of human capital $H_{t, s}$

$$
H_{t, s}=H_{0, s} e^{\left(\frac{s \hat{A}_{t}+\gamma \hat{B}_{t}}{1-\beta}\right) t}
$$

Assuming that all individuals start with the same level of human capital $H_{0, s}=1$, the overall level of human capital can be calculated - by integrating over equation (B.1) for all individuals - as

$$
H_{t}=\int_{0}^{1} H_{t, s} d s=\int_{0}^{1} e^{\left(\frac{s \hat{A}_{t}+\gamma \hat{B}_{t}}{1-\beta}\right) t} d s
$$

Solving this integral and substituting $s=0$ and $s=1$ leads to the solution for $H_{t}$

$$
H_{t}=\frac{(1-\beta)\left(e^{\left(\frac{\hat{A}_{t}+\gamma \hat{B}_{t}}{1-\beta}\right) t}-e^{\left(\frac{\gamma \hat{B}_{t}}{1-\beta}\right) t}\right)}{t \hat{A}_{t}}
$$

This expression gives us the overall level of human capital at time $t$. 


\section{Appendix C}

The Hamiltonian for the firm's profit maximization problem is defined as

$$
\Pi=K_{t}^{\alpha}\left(A_{t} \int_{0}^{1}\left((1-\phi)\left(1-u_{s}\right)\right) H_{t, s} d s\right)^{v}-r K_{t}-w_{t} \int_{0}^{1}\left(1-u_{s}\right) H_{t, s} d s+\lambda_{3}\left(\int_{0}^{1}\left(\phi\left(1-u_{s}\right)\right) H_{t, s} d s\right)^{\delta} A_{t}^{\xi}
$$

The amount of human capital available to the firm can be found by solving

$$
\int_{0}^{1}\left(1-u_{s}\right) H_{t, s} d s=\int_{0}^{1}\left(\frac{-((1-\beta)+\beta s) \hat{A}_{t}-\beta \gamma \hat{B}_{t}+(1-\beta)(1-\tau) r}{(1-\beta)\left(-(1-s) \hat{A}_{t}+\gamma \hat{B}_{t}\right)+(1-\beta)(1-\tau) r}\right) e^{\left(\frac{s \hat{A}_{t}+\gamma \hat{B}_{t}}{1-\beta}\right) t} d s
$$

which leads to the following solution

$$
\frac{-\beta\left(e^{\left(\frac{\hat{A}_{t}+\gamma \hat{B}_{t}}{1-\beta}\right) t}-e^{\left(\frac{\gamma \hat{B}_{t}}{1-\beta}\right) t}\right)}{\hat{A}_{t} t}+\frac{\left(-\hat{A}_{t}+(1-\tau) r\right)}{1-\beta}\left[\sum_{n=1}^{n=\infty}\left(\frac{(n-1) !(1-\beta)^{n}}{\hat{A}_{t} t^{n}\left(-(1-s) \hat{\left.A_{t}+\gamma \hat{B}_{t}+(1-\tau) r\right)^{n}}\right.}\right) e^{\left(\frac{s \hat{A}_{t}+\gamma \hat{B}_{t}}{1-\beta}\right) t}\right]_{s=0}^{s=1}
$$

For convenience, this is defined as $H_{t, f}$. The Hamiltonian can now be rewritten as

$$
\Pi=K_{t}^{\alpha}\left(A(1-\phi) H_{t, f}\right)^{v}-r K_{t}-w_{t} H_{t, f}+\lambda_{3}\left(\phi H_{t, f}\right)^{\delta} A_{t}^{\xi}
$$

The control variables are $K_{t}, H_{t, f}$ and $\phi$. Taking partial derivatives with respect to the control variables gives equations (C.2) to (C.4):

$$
\frac{\partial \Pi}{\partial K_{t}}=\alpha(1-\phi)^{v} K_{t}^{\alpha-1} A_{t}^{v} H_{t, f}^{v}-r=0
$$




$$
\frac{\partial \Pi}{\partial H_{t, f}}=v(1-\phi)^{v} K_{t}^{\alpha} A_{t}^{v} H_{t, f}^{v-1}-w_{t}+\lambda_{3} \delta \phi^{\delta} A_{t}^{\xi} H_{t, f}^{\delta-1}=0
$$

$$
\frac{\partial \Pi}{\partial \phi}=-v(1-\phi)^{v-1} K_{t}^{\alpha} A_{t}^{v} H_{t, f}^{v}+\lambda_{3} \delta \phi^{\delta-1} A_{t}^{\xi} H_{t, f}^{\delta}=0
$$

Taking partial derivatives with respect to the state variable $A_{t}$ gives the following differential equation for $\lambda_{3}$

$$
\dot{\lambda}_{3}=-\frac{\partial \Pi}{\partial A_{t}}=-v(1-\phi)^{v} K_{t}^{\alpha} A_{t}^{v-1} H_{t, f}^{v}-\lambda_{3} \xi \phi^{\delta} A_{t}^{\xi-1} H_{t, f}^{\delta}
$$

Furthermore,

$$
\dot{A}=\left(\phi H_{t, f}\right)^{\delta} A_{t}^{\xi}
$$

Dividing (C.6) by $A_{t}$ and taking growth rates, gives the following relation between the growth rates of human capital and private knowledge

$$
\hat{H}_{t, f}=\left(\frac{1-\xi}{\delta}\right) \hat{A}_{t}
$$

Rewriting (C.2) in growth rates, and making use of (C.7), gives a relation between the growth rates of physical capital and private knowledge

$$
\hat{K}_{t}=\left(\frac{1+\delta-\xi}{\delta}\right) \hat{A}_{t}
$$


Rewriting (C.3) in growth rates, and making use of (C.7) and (C.8) leads to the conclusion that wages grow with the same rate as private knowledge

$$
\hat{w}_{t}=\hat{A}_{t}
$$

The part of the human capital stock available to firms that is devoted to the production of new knowledge is equal to

$$
\phi=\frac{\delta}{\left(\frac{1-\xi}{\delta}\right)-\delta+\xi}
$$

It can be shown that $0<\phi<1$. 


\section{Appendix D}

The accumulation of the stock of physical capital $K_{t}$ equals the sum of the individual capital stock increases

$$
\dot{K}_{t}=\int_{0}^{1} \dot{K}_{t, s} d s
$$

Making use of equations (2), (4), the definition for $H_{t, f}$

$$
H_{t, f}=\int_{0}^{1}\left(1-u_{s}\right) H_{t, s} d s
$$

and the fact that

$$
K_{t}=\int_{0}^{1} K_{t, s} d s
$$

equation (D.1) can easily be rewritten as

$$
\dot{K}_{t}=(1-\tau) r K_{t}+(1-\tau) w_{t} H_{t, f}-e^{\left(\frac{(1-\tau) r-\rho}{\sigma}\right) t}
$$

The steady-state relations between the growth rates of $K_{t}, H_{t}$ and $A_{t}$, as expressed in equations (C.7) and (C.8), leads to the conclusion that the growth rate of the physical capital stock equals that of consumption:

$$
\hat{K}_{t}=\frac{(1-\tau) r-\rho}{\sigma}
$$

